\title{
The Structural Analysis of BPO in China
}

\author{
Pei-Zhi Wang ${ }^{1, a}$, Hong Zhu ${ }^{2, b,{ }^{*}}$ \\ ${ }^{1,2}$ Shandong university of Finance and Economics, shun gen Road 40, Ji Nan City ,Shandong \\ Province, China \\ awpzmail@126.com, b1558280716@qq.com \\ ${ }^{*}$ Corresponding author
}

Keywords: BPO, Trade structure, Statistical analysis.

\begin{abstract}
The paper is to do research on major issue of the trade development of china BPO business. And the methodology used relates to statistical analysis based on the date (2008 2014), trying to prove the trade development about china BPO business in the micro environment. As a result, the article figures out a solution to trade development about china BPO business which proves to be positive to balance china's trade structure in the future.
\end{abstract}

\section{Introduction}

Since the year from 2008 to 2014(October), our outsourcing service got a rapid development in total, especially in our BPO, although the 2008 financial crisis causes a deep influence on its development. However, we could not ignore the fact that the increase ratio of our BPO business is still in flat, and those industry covered by BPO is still located in the lower end of value chain, which impede the development of our economic. Admittedly, there are various factors contributing to this phenomenon, but it is undeniable that the unbalanced structure among BPO is categorized as one of the major elements. Thus, it is imperative to analysis the specific different structure between ours and other developed countries.

\section{Methodology}

According to the correlative knowledge of statistics, comparative analysis can be used to explain some economic phenomenon, in this paper, we take advantage of different countries in a certain period, then plug these figures into the fundamental equations:

INDEX $=\mathrm{t} / \mathrm{T}$

As described, "t "means a certain indicator belongs to the overall data, while " $\mathrm{T}$ " means the overall data. Finally we could find out structure difference between two countries.

Data Interpretation. Based on Ministry of Commerce of the people's republic of China from 2008 to 2014 October, first of all, we would find that China Outsourcing Service has a rapid growth. Especially in recent three years(from 2012 to 2014October), the absolute figure is obvious, for example, in 2014,outsourcing service is about 61180 million US dollars .However when separated BPO from outsourcing service we could find some change, as is shown, BPO business does not take up a considerable part of the total outsourcing service in average. On all counts, you will find that the total amount is relatively stable. As is described in chart 1 .

Tab. 1 Outsourcing service and BPO in China(unit: Million USD)

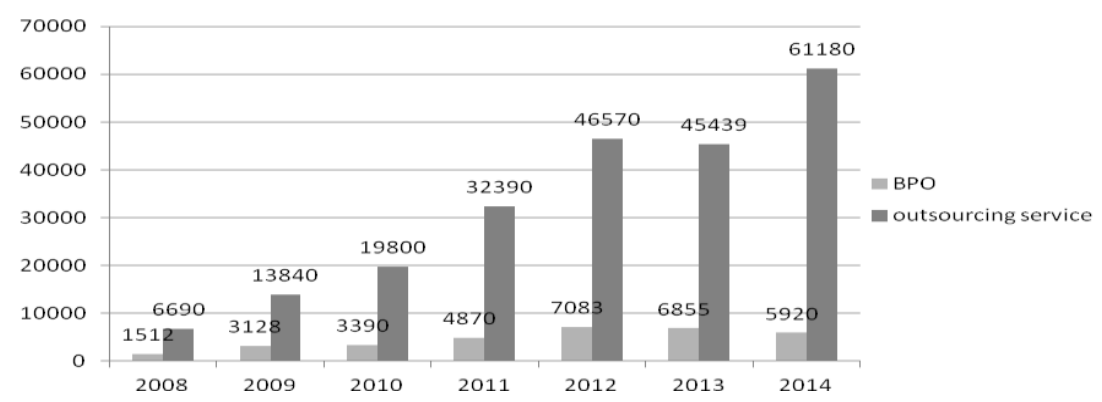

SOURCE: Ministry of Commerce of the People's Republic of China 
Taking advantage of the equation INDEX $=t / T$. " $t$ " means BPO, and " $T$ " means outsourcing service. Then we can see the result of the increase rate of BPO (in table 1).although the absolute figure of BPO grows rapidly from 2008 to 2012, the INDEX indicates that the comparative figure of BPO is decreasing year by year. So essentially, our BPO business needs great strides in development.

Tab. 2 the ratio between BPO and outsourcing service(unit: Million USD, \%)

\begin{tabular}{|l|l|l|l|l|l|l|l|}
\hline Years & 2008 & 2009 & 2010 & 2011 & 2012 & 2013 & 2014 \\
\hline BPO & 1512 & 3128 & 3390 & 4870 & 7083 & 6855 & 5920 \\
\hline Outsourcing service & 6690 & 13840 & 19800 & 32390 & 46570 & 45439 & 61180 \\
\hline INDEX & $22.6 \%$ & $22.6 \%$ & $17.1 \%$ & $15.0 \%$ & $15.2 \%$ & $15.1 \%$ & $9.8 \%$ \\
\hline
\end{tabular}

SOURCE: Ministry of Commerce of the People's Republic of China

Transaction structure analysis.From China's service outsourcing research center, we search the figure about our outsourcing service including ITO, BPO and KPO, according to these information, we see that BPO is located in disadvantage station whether in absolute data or in comparative data. These years with the speed development of KPO, and the prominent fundamental status of ITO, our BPO business looks more depression, so how to increase the rate of BPO in our outsourcing service becomes very important .As is described in table 3.

Tab. 3 The rate of ITO, BPO and KPO from 2011 to 2013(unit: \%)

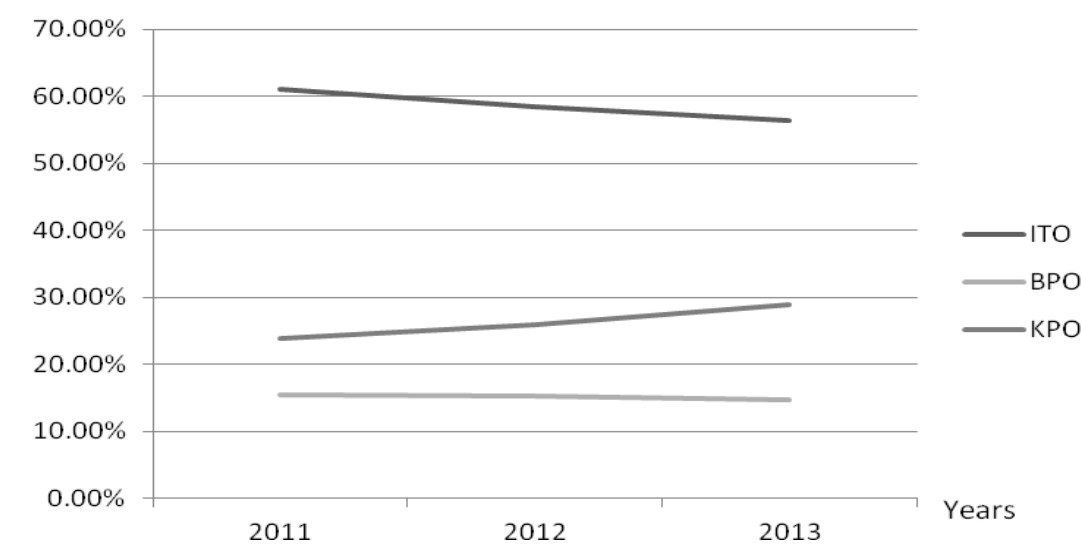

SOURCE: Ministry of Commerce of the People's Republic of China

Industrial structure analysis .According to IDC ,in the year of 2014, the top five outsourcing service industry are IT service, manufacturing, others(Engineering design), finance and Insurance and Retail and wholesale .However, It is generally known that BPO is mainly expert in processing design ,such as internal management processing design and supply chain design and so on. Thus by comparing, we could make the conclusion that BPO business covered little or in lower end of value chain in the main field, which causes great influence on economic growth .so It is high time for our BPO to innovate and make an efforts to participate in international division .the detailed information could be seen clearly in table 4.

Tab. 4 Main industry in outsourcing service

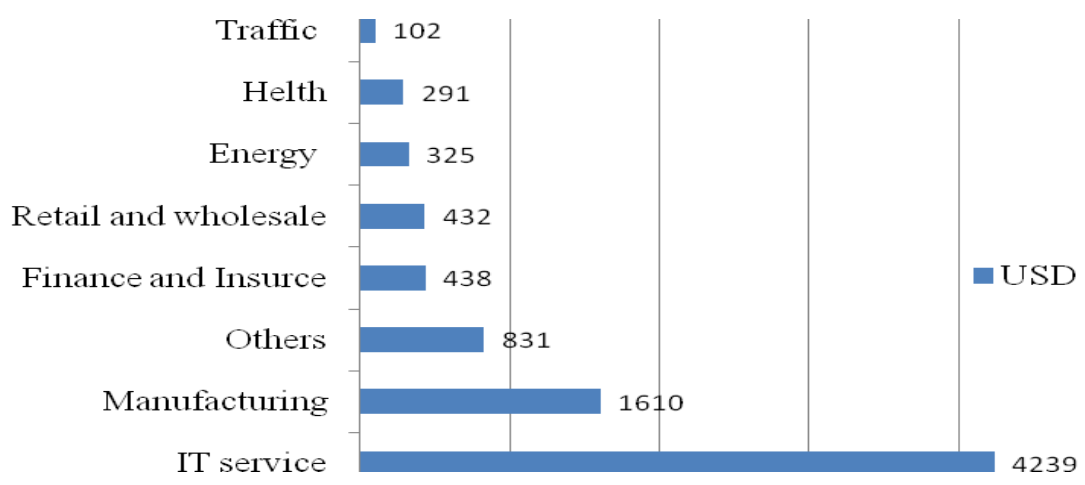


Market structure analysis.Based on Ministry of Commerce of the people's republic of china, china is regard as an outsourcing recipient country in the process of development, but due to getting a later start, compared with developed countries, there is still a great gap between with developed countries, such as United State, EU and Japan. Now a case study based on the data of 2012 could be articulated in the year of 2012, China outsourcing service recipient countries are as follow: USA, European, Japan, Hang Kong and Singapore. as a result of most of these are developed countries, so when we recipient their business, we generally in lower end of value chain or a lower technology content, which impede Chinese firm's radical innovation and technology advance. As is shown in table 5.

Tab. 5 BPO offshore outsourcing service market in china(unit: \%)

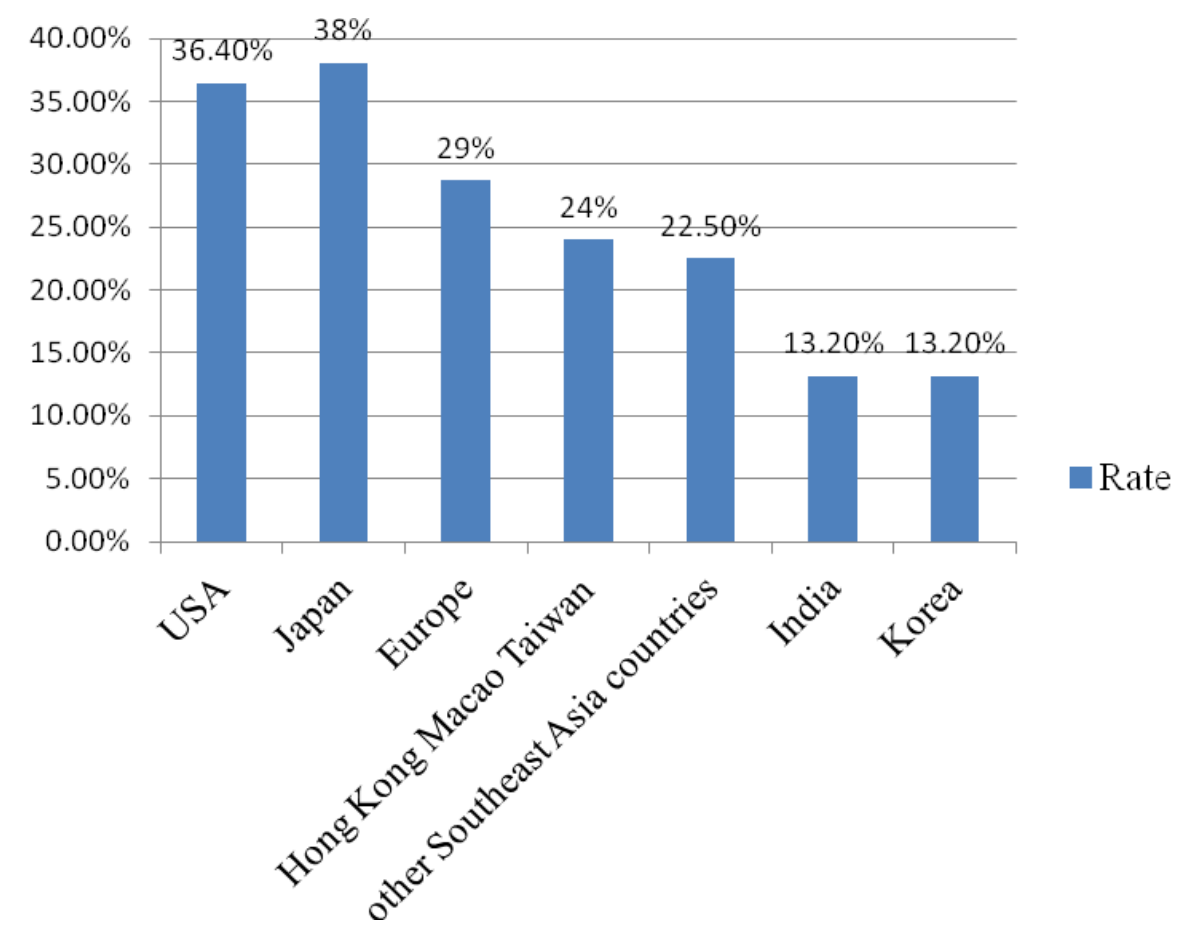

SOURCE:China service outsourcing network

\section{Summary}

By analysis the structure of BPO in China, including Transaction structure, Industrial structure and market structure, conclusions and future work are summarized as follows:

First of all, our BPO needs to continue developing. Efforts to improve its ratio in outsourcing service,so to have a bigger share of marketing, on one hand, innovating its key business such as the overall solutions service and the data processing service; and on the other hand, increasing its R\&D and human capital. Secondly, our outsourcing service industry should improve its brand impact especially attaching great importance to the quality of service and the attention to after-sales service, what's more, taking an active part in international division becomes more and more essential.nowadays,USA,Japan and Eruope are the first three market in outsourcing service,so try to enter their market is particularly improtant.

Thirdly, our government should provide relevant policy support as well as incentive programs, in order to pave the way for our industry's exciting. In regard to policy support,our goverment should promote the development of emerging industry in outsourcing service especially in BPO.when it comes to incentive programs, it cannot only including money support but also the cultivation of professional talents.

\section{Acknowledgement}

This article is sponsored by Shandong Provincial Science and Technology Development Planning project(2014GGH213001) " Study on the early warning mechanism of agricultural industry damage of Shandong province from the perspective of global value chain" hosted by Wang Peizhi; Shandong Provincial Natural Science Foundation project(ZR2013GM013) "Research on agricultural products 
trade's marginal measures and upgrading route of Shandong Province" hosted by Wang Peizhi; Shandong Provincial Academy of Social Sciences project(14AWTJ01-15) " Research on early warning system of financial internationalization development in Shandong Province" hosted by Wang Peizhi; Shandong Education Department's Project (sdyy11201) "Research on Innovation of Bilingual Teaching of Graduates in International Business, Shandong University of Finance and Economics" hosted by Liu Xinying; Project (jy201212 )"Research on Combining Chinese Graduates with Foreign Students in Teaching International Economics and Trade in English" hosted by Liu Xinying; Shandong science and Technology Department Project(2014RKB019A6) "Research on agricultural industry security of Shandong province from the perspective of open market" hosted by Liu Xinying.

\section{Reference}

[1] Klepper R. Jones O W. Outsourcing information technology ,systems and services [M].Prentice Hall,NJ.2009.

[2] Quinn J B, Hilmer F G. Strategic outsourcing [J].Sloan Management Review, 2008.

[3] Thomas J. Holmcs and Julia Thomton Snider,A theory of outsourcing and wage decline: American Economic Journal. Pp, 38-39. 2011.

[4] Jia Li Liu, BPO development research in china: Economic aspect Intemet fortune .pp, 69-70, 2009.

[5] Wang haibo. competitive analysis of china undertaking business process outsourcing.pp1-33,2008.

[6] Wang suqin., (eds).International trade in service: university of international business and economic,2011.

[7] The national bureau of statistics online.www.stats.gov.cn.

[8] Ministry of Commerce of the People's Republic of China online. coi.mofcom.gov.cn/article/bt/w/? 